

\section{KNOWLEDGE ORGANIZATION Contents}

\section{Editorial}

Reminiscenses and the One Big Hope

\section{Articles}

Bennet, D.C.: The Intcrnationalization of Scholarship and Scholarly

Societics in the Humanities and Social Sciences.

Walker, Th.D.: Medieval Faceted Kno wledge Classific ation.

Ramon Llull's Trees of Science.

Gödert, W.: Information as a Cognitive Construction: A Communication-theoretic Model and Consequences for Information Systems Yi, Hong; Jin, Zhang: The Dewey Decimal Classi fic ation in China ....... 213 Riggs, Fred W.: Onomantics and Terminology.

Part III: Formats, Borrowed Terms and Omissions

\section{Reports and Communications}

ISMICK'96 (225) - Austrian Commission for Subject Cataloguing (225) British Classification Research Group (225) - Infoterm - a Fresh Start (225) European Association forTerminology founded at Southern Denmark Business School (226) - Ordinal and Symbolic Data Analysis (226) - Courses on Conceptual Data Analysis and Conceptual Knowledge Processing, Darmstadt 1997 (226) - Languagcs and the Media (198) - IFCS-96. Data Science, Classification and Related Methods, Japan, March 1996 (198) - Society of Indexers in Ireland, Sept. 1997 (205) - Search results also available at DIMDI via email (205).

\section{ISKO News 26}

The IS KOGeneral Secretariat Mo ved fromFrankfurt, Gcrmany to Copenhagen, Denmark (227) - Changes in the Editorship of ISKO's Joumal (227) - New Publisher of ISKO's Journal and its Series (227) - Calling for ISKO's New International WGs (227) - IS KO WG "Educ ation and Training" (227) - ISKO WG "Knowledge Indexing and Supply" (227) - ISKO WG "Humanities/ Fiction" (227)-Fiction, OPACs, Net works. AResearch Seminar in Copenhagen, Nov. 1996 (228) - Compatibility and Integration of Order Systems (192) SCIRE. VolI (1995)Number 2 (192).

\section{FID/CR News 41}

Ranganathan Award forClassific ation Research (229) - New Chair of FID/CR (229) - Testimony of Gratitude (229) - Annual Report of FID/CR, 1996 (229) - IFLA Section on Classification and Indexing. Rcview of Activities, 1995$1996(230)$

\section{Book Reviews}

Steierwald, Ulrike: Wissen und System. Zu Gottfried Wilhelm Leibniz' Theorie einer Uni vcrsalbibliothck. (Knowledge and system. On G.W. Leibniz' theory of a universal library). (Wilhelm Totok)

Holley, R.P.; McGarry, D.; Duncan, D.; Svenonius, E. (Ed's.): Subject Indexing: Principles and Practices in the 90's. Proceedings of the IFLA Satellite Meeting held in Lissabon, Portugal, 17-18 August 1993.

(Mira Micacic, Mi ma Willer)

Budin, Gerhard: Wie (un)verständlich ist das Soziologendeutsch?

Begriffliche und textuclle Strukturen in den Sozialwissenschaften.

(How (in)comprehensible is the German of sociologists? Conceptual and textual structures in the social sciences). (Heribert Picht)

Gerlach, Uwe; Gerlach, Gordona: Moderne Mentaltechniken.

Neue Wcgc zu Tiefenentspannung und Wohlbefinden.

(Modern mental techniques. New ways to wards depth meditation

and well-feeling). (Hclmut Löckenhoff)

Knowlege Organization Literature 23(1996)'No.4

Ain

Dr.M.P. SATIJA (Book Review Editor), Guru Nanak Dev
University, Sclıool of Library and Information Science, Amritsar-143005, India

\section{Consulting Editors}

Prof.Kcnncth G.B.B^KEWELL, 9, Greenacre Road, Liverpool, L25 OLD, U.K.

Prof.PaulineA.COCHRANE,GSLIS. University of Illinois, 410 David Kinlcy Hall, 1407 West Grcgory Drive, Urbana, IL 61801-3680, USA

Prof.Dr. Emilia CURRAS, Universidad Autonomade Madrid, Dcpt. de Doc. Cient. Fac. de Ciencias, Canto Blanco, Madrid 34, Spain

Mr.Jens B.FRIIS-IIANSEN, Hocsicrkocbvcj 7, DK-2970 Hoersholm, Dcmmark

Mr. Christian GALINSKI, INFOTERM, Heincstr.38, A-102I Vicnna

Mr.AlanGILCHRIST, 38 Ship Street, Brighton BNI 1 A $\mathbf{E}$, U.K

Prof: Wilfricd GÖDERT,FHBD, Claudiusstr. 1,D-50678Köln

Dr.M.A.GOPINATH,DRTC, Indian Statistical Inst., 81hMile, Mysore Road, R. V.Collcge P.O., Bangalorc-S6005\%, India

Prol.Eric de GROLIER, ISSC, 1, ruc Miollis, F-750 15 Paris, France

Prof.Dr.Roland HJERPPE, Linköping University, Dept. of Computcr and Information Science, S-58183 Linköping

Prof.Krishan KUMAR, Dept.ofLibr.\& Inform.Sci., Univ, of Delli, Dclli- 110007 , India

Ms.Joan MITCHELL, Editor DDC, Library of Congress, DecimalClassification Division, Washington, DC 20540-4330, USA

Prol.YukioNAKAMUR^, 14-8, Nisikata-I, Bunkyo-ku, Tokyo I13, Japan

Dr.Giliola NEGRINI, Consiglio Nazionalc delle Riccrelı, ISRDS, Via Cesarc de Lollis 12, I-00185 Roma, Italy

Prof.Dr.Roy RADA, Prof. of Softwarc Enginccring Virtual Univcrsity $\Lambda$ cad. Off., Washington State University, Pullınan, W^991 64-2752, USA

Prof.Dr.Winfried SCHMITZ-ESSER, Odcrfelderstr.13, D20149r Iamburg

Prof.Dr.Eugcniusz SCIBOR, IINTE, Broniewskigo 83-157, PL-0I-876 Warszawa, Poland

Dr.Ot toSECHSER, In derEy 37, CH-8047 Zürich

Prof.Dr.DagobcrtSOERGEL, Collegc ofLibr.\& Inform.Serv., Univcrsityof Maryland, Collcgc Park, MD, 20742, USA

Dr.Eduard SUKIASYAN, Russian State Library, Vozdvizhenka, 3,Moskva 10 I00, Russia

Dipl. Ing. RudolfUNGVARY, Nyul u. 14, H-1026Budapcsı, Hungary 
UDC 025.4+168+001.4(05)

\section{KNOWLEDGE ORGANIZATION}

International Journal devoted t o Concept Theory, Classification, Indexing and Knowledge Representation

Editors: Dr.I.Dahlberg, Frankfurt; Dr.R.Fugmann, Idstein, Prof.J.M.Perreault, Huntsville, AL, USA.

Editorial Office: c/o Dr.I.Dahlberg, Woogstr. 36a, D-60431 Frankfurt. Tel.069-52 36 90, FAX: 069-52 0566

Issue frequency: 4 x/ann. Annualsubscription rates: Institutions per volume DM 128.-, Individuals pervolume $20 \%$ less, if direclly ordered from INDEKS Verlag. Single issues: DM 32.- Back issues available, ask for special offer. Subscription included in membership fee for members of the International Societyfor Knowledge Organization (ISKO). MwSt and postage are included; no Air Mail delivery possible. Advertisingrates: Advertising rate card No.3. Advertising fact sheet with details of mechanical requirements and closing date available upon request.

Publisher: INDEKS Verlag, Woogstr.36a, D-60431 Frankfurt, Tel.069-52 36 90; FAX 069-52 0566.

Please take into account that the ERGON Verlag at Würzburg accepted the journal Knowledge Organization from the Indeks Verlag at Frankfurt. From Vol. $1 / 97$ on the ERGON Verlag will deliver all titles, which were formerly available at the Indeks Verlag.

All Rights reserved. Printed in the Federal Republic of Germany 1996 by Druckerei H.Guntrum II KG. PF 180, D-36110 Schlitz/Hessen.

\section{Contents page}

Bconetl, D.C.: The internationalization of scholarship and scholarly societies in the humanities and social sciences. Knowl.Org. 23(1996)No.4, p. 193-198

The paper focusses on the practical issues of institutions and rcsources rclating to a conf ercnce held in November 1994 on the topic, organized by the American Council of Learned Societies (ACLS) which cmbraces the U.S. scholarly community in the humanities and social sciences. The results of statcments of conf erence participant son the int crnationalization of ist activitics and on the int crnationalization of scholarship in their fields have bcen summarized here.

(KO)

Walker, Th.D.: Medieval faceted knowledge classification: Ramon Linll's Trees of Science.

Knowl.Org. 23(1996)No.4, p.199 - 205, 27 rcfs.

Ramon Llull (1232-1316) wrote many didactic and theorctical works that demonstrate an cxhaustive and creative approach to thcorganization of knowledgc. His encyclopedicArbre desciència (1296) was a multi-volumc summation of human knowledgc, organized according to a plan that could bc applied to other works. Set against a background of Llull's other trcc-based works, including the Libre del gentil e dels tres savis (1274-89), and the Arbre de filosofia desiderat (1294), the Arbre desciència is described and analyzed as a faceted classification system.

(Author)

Gödcrt, W.: Information as a cognitive construction: A communication-theoretic model and consequences for inf ormation systems.

Knowl.Org. 23(1996)No.4, p. 206-212, 15 refs.

In this paper a model for understanding the conccpt of information is presented and how the proccsses of externalization and perception ofinformation by human bcings could bc understood. This model is different from the standard information theoretic model. It combines the understanding of cognitive information processingas an actof information gcneration from sense impressions with communication theorctic considcrations. This approach can be of value for any system that is rcgarded as a knowlcdge systcm with an in-built ordering structure. As an application some consequences will be drawn for the design of information systems which claims to handle information itself (c.g. multimedia information systems) instead of giving refercnces to bibliographic cntities.

(Author)

Vol.23(1996)No.4

Yi, Hong, Jin, Zhang: The Dewey Decimal Classification in China.

Knowl.Org. 23(1996)No.4, p. 213-215, 14 refs.

In China, the Deivey Decimal Classification (DDC) is one of the most influcntial classifications. It had a great impact on the dcvelopment of Chinesc classification. A comparison betivecn DDC and thrce representative Chinese classifications corrcsponding to ancient, modcrn and contemporary times, illustratc the influcncc of DDCon Chinesc classifications. The celcbration of the 120th anniversary of the DDC is a good time to rcview its introduction, application, devclopment and impact in China.

(Authors)

Riggs, F.W.: Onomantics and Terminology. Pt.III: For'mats, borrowed terms and omissions.

Knowl.Org. 23(1 996)No.4, p. $216-224,29$ refs.

Third part of a scrics of articlcs of wh ich Pt. 1 was published in KO 23(1996)No.1, p.25-33, Pt.2 in No.3, p. 157-168. Pt.4 will follow in KO 24(1997)No.1. In addition to the important distinctions betwecn the fundamental concepts and terms (tags) used in Onomantics and Terminology, as reported in the first t wo parts of this essay, scveral other interesting comparisons can be madc. First, with reference toformats, both the structure and nomcnclature uscd for termino logical entries (records) in ISO 1087 parallel those found in dictionaries and suggest a semantic rather than an onomantic point of view. Sccond, a large number of borrowed term.s taken from Lexicography and Linguistics can be found in th is glossary for the terminology of Tcrminology. Sometimes the definitions for these terms identify them as borrowed concepts drawn from the vocabulary used by lcxicographers. However, somctimes new mcanings arc stipulated for these tcrms without any markings to show that they are not borrowed conccpts. Moreover, in all thesc cases, since the original and the ncivly st ipulated concepts arc similar, ambiguity is unavoidablc. Third, some conccpts that might be usefill for tcrminologists are not included in ISO 1087: a feiv examples arc cxplained. They are all concepts which lexicographers do not necd and, consequently, they have no terms for them. It secms apparcnt that they have beenomitted from the vocabulary of Tcrmino logy simply becausc they arc new conccpts without established terms. To explain the reasons for the formats, terms and omissions found in the leading glossary for the terminology of Terminology takcs us into a realm of speculation that is too complicated for inclusion herc, but 1 will discuss it in Part IV of this serics, with a focus on the problems of neologisms.

(Author) 


\section{Scope}

The more scientilic data are generated in the impetuous present limes, the more ordering energy needs to be expended to contol these data in a retricvable fashion. With the abundance of knowledge now available the questions of new solutions to the ordering problem and thus of improved classification systems, methods and procedures have acquired un foreseen significance. Formatuy years now they have heen in the focus of interest uf information scientists the world over.

Until recently, the special litcrature relevant to chassification was published in experts of the various lields, such as

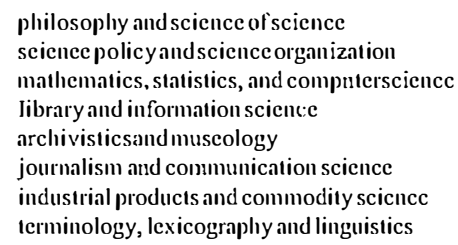

13cginning 1974, KNOWLEDGE ORGANIZATION (formerly INTERNATIONALCLASSIFICATION) has been serving is a common plat form for the discussion of both theorcticil bickground questions and practical application problems in many areas of concertu. In ench issue cxperts from many countries commcnt on questions of an adequate structuringand construction ofordcring systemsand onthe problems of their usc in opcning the information contents of new litcrature, of data collectioiss and survey, oftabularworks and of other ohjects of scientific iatterest. Theireontributions have been concerned with

(I) clarifying the theoretical foundations (general ordering theory, seienec theoretical bases of classilication, data analysis and reduction)

(2) describingpractical operations connected with numerical taxonomy/ classification, as well as applications of classification systems and thesauri, manual and machine indexing

(3) tracing the history of classilication knowledge and methodology

(4) discussing questions of education and training in classification

(5) concerning themselves with the problems of terminology in general and with respect to special fields. piecemeal fashion, scittered over the numerous techuical journals serving the

Aims

Thus, KNOWI.EDGE ORGANIZ^TION is meant to be a programme for the improvement of classification methods and processes, a for um for discussion forall those intcrested in the organization of knowledge on in universal or a subject-ficld scalc, using concept analytical and/or concept-synthctical approaches as well a unucricalproceduresand comprisingalso the intellectual and automaticcompilation and usc of classification systems and thesauri in all liclds of knowfedge, witl specialattentionbeing given to the problems of terminology.

KNOWLEDGI:ORGANIZATIONpublishes original articles, reportson conferences and similar communications, the Newsletters of the Intcrnational Society fo KnowledgeOreanization (ISKO News) and the Committceon Classification Rcsearch of the International Fedcration for Information andDocumentation (FID/CR News) as well as book reviews, letters to the editor, and an cxtensive anmotated bibliography of recent classification and indexing litcrature, coveringnow some 500 itcms in cach issuc.

KNOWLEDGEORGANIZATION shonld there fore be available at every university and rescarch Jibrary of every country, at every in formation center, at colleges and schools oflibrary and information scicnec, in the handsof everybody interested in the ficlds mentioned above and thus also at every oflice for updating inlormation on any topic related to the problems of order in our iifformation-flooded times.

KNOWLEDGEORGANIZATION was lounded in 1973 by an international groun of scholars with a consulting hoard of editors representing the world's regions, the special classification ficlds, and the subject arcas involved. From I 974-1 980 IC was published by K.G.Saur Vcrlag, Müuchen. Back issues ofI $978-1992$ are available from INDEKS Verlag, too. (The I 4 volumes of 1978-1992 are offered now at the highly reduced price of DM 200.-)

Asof I 989, KNOWLEDGEORGANIZATIONhasbecome the officialorgan of the INTERNATIONALSOCIETY FOR KNOWLEDGEORGANIZATION(ISKO) and isincluded lorevery ISKO-member, personal or institutional in the membership fec (DM 60.-/I)MI 20.-)

Ratex: From 1990 on lor 4 issues/ann. (including indexes) DMI 28.- No airmail delivery any longer. Mcmbership rates sce abovc. - INDEKS Verlag, Woogsı. 36a D-60431 Frankfiut.

Instructions for Authors

Manuscripts may be submitted in cither English, German or French to the editor-in-chicf in tivo sets (the original and onc copy) typed in double spacc, comprising between 1500 to 3000 words. They should be accompanicd by an English indicative abstract of 100-200 words. The contributions are refereed. Criteriafor acceptance will be appropriatencss to the field of the journal (see Scopc and Aims) taking into account the merit of the content and its prescntation. Papers are accepted with the understanding that they have not been published, submitted or accepted for publication clscwherc and that, if the work received of ficial sponsorship, it has becn duly released for publication. Authors will usually be notificd within 6 to 10 weeks. Unless specifically requested, manuscripts or illustrations will not be returned.

The text of the contributionsshould be structured by subheadings; it should contain (a) an introduction, stating the purpose, (b) a description of materials and methods in sufficient detail, (c) information on results or systems devcloped, and (d) a conclusion on and/or summarization.

References should be listed at the end of the paper with the numbers in brackets referring to such numbers in brackets within the text part.

Additional notes should be indicated in the text by lift ed single numbers behind a word and cqually collected with their texts at the end of the paper under the heading Notes

Journal References should contain the names and initials of all authors, full titles of the publication, abbreviation of the journal according to the ISO Standard 4, volume number, ycar of publication in brackets, issue numbcr and first and last page numbers. Monograph References should give the name(s) of the author(s), full title, edition, place of publication, publisher, year and the number of pages.

Examples: Brandhorst, J.P.J.: Quantifiability in iconography. Knowl.Org. 20(1993)No.1, p.12-19, 11 rcfs.

Hunter, E.J .: Classification made simplc. Aldershot, GB: Gower 1988. $115 p$

Illustrations should be restricted to the necessary minimum. Graphs and diagrams should be supplied as black and white drawings suitable to reproduction. Half-tone illustrations should numbered lightly with a soft pencil on the back. Numbered legends should be attached on a scparatc shect.

Tables should be typed doublc-spaced on a scparatc shcet contain a number and a titlc at the top and be cited in the text. Each column should have a heading.

Authors shall reccive 25 reprints of their papers free of chargc. Additional reprints may be ordered.

Corrections in gally proof exceeding 10\% of the typesetting costs will be charged to the author.

Contributions on micro flexible discs are welcome if delivered in DOS compatible standard software such as Word (DOS or Windows), WordStar, WordPcrfect, DCA/RFT-files or plain ASCII code - our standard is Word/DOS (Word/Windo ws 6.0) and PageMaker 6. be sharp, well-contrasted glossy prints. Illustrations should be 